\title{
Gold film-catalysed benzannulation by Microwave-Assisted, Continuous Flow Organic Synthesis (MACOS)
}

\author{
Gjergji Shore, Michael Tsimerman and Michael G. Organ*
}

\section{Full Research Paper}

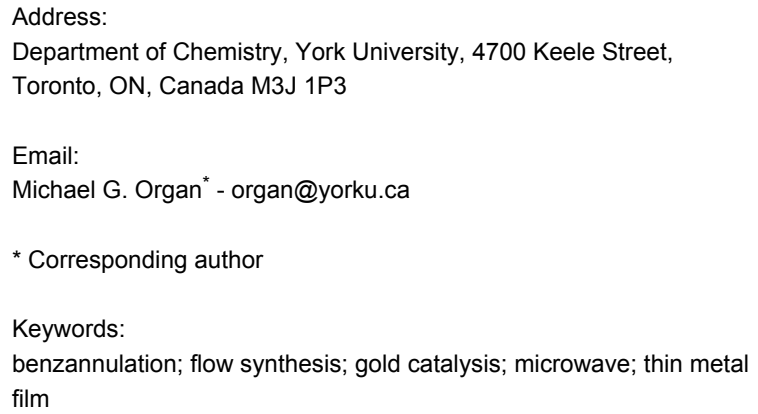

Beilstein Journal of Organic Chemistry 2009, 5, No. 35 doi:10.3762/bjoc.5.35

Received: 15 April 2009

Accepted: 08 July 2009

Published: 21 July 2009

Guest Editor: A. Kirschning

(C) 2009 Shore et al; licensee Beilstein-Institut.

License and terms: see end of document.

\begin{abstract}
Methodology has been developed for laying down a thin gold-on-silver film on the inner surface of glass capillaries for the purpose of catalysing benzannulation reactions. The cycloaddition precursors are flowed through these capillaries while the metal film is being heated to high temperatures using microwave irradiation. The transformation can be optimized rapidly, tolerates a wide number of functional groups, is highly regioselective, and proceeds in good to excellent conversion.
\end{abstract}

\section{Introduction}

Microwave-assisted organic synthesis (MAOS) has had a significant impact on organic and medicinal chemistry by dramatically shortening reaction times, producing cleaner product mixtures, and making high-energy transformations routine that might otherwise be avoided [1,2]. Within the last five years, microwave technology has also been applied to reactions performed in a flowed format $[3,4]$. Flowed chemical synthesis offers numerous advantages over traditional batch-reactor technology [5-24]. Independent inlet streams allow reactive intermediates to be kept separate until brought together in miniscule amounts to react immediately; this rapidly depletes the starting materials and continuously physically moves the product away from the infusing stream. In batch reactors, product molecules form in the presence of a vast excess of starting materials that can lead to significant byproduct formation. Further, a moving synthesis platform allows for in-line analysis and instantaneous changes to reaction conditions for process optimization that can be automated readily. To gain the full advantage of working in flow, reactions should proceed very rapidly and ideally reach completion during the time in which the reactants reside in the flow tube. Microwave heating has been used to drive a wide variety of reactions to high levels of completion in a flowed format [5-24].

We have demonstrated that thin-metal films on the walls of narrow tubes can impart tremendous rate accelerations on 
flowed reactions that are being simultaneously microwaved [25-28]. These accelerations can be a result of direct catalysis by the film itself, the tremendous temperatures attainable by microwaved metal films, or a combination of the two. In cross coupling processes, the film has been demonstrated itself to be capable of catalyzing Suzuki-Miyaura and Heck reactions, i.e., Pd-thin films promote these transformations without any additional catalyst being added to the reactant stream(s) that enter the flow tube [28]. Without microwave irradiation, the abovedescribed cross-coupling reactions did not proceed indicating that there is not only a catalytic effect, but also a pivotal heating effect supplied by the film. More recently we have shown that a gold film in the same flow reactor is highly effective for hydrosilylation reactions [25] and we were interested both to expand the use of gold films in synthesis using MACOS and in exploring complex, multi-step catalytic processes in flow.

The benzannulation reaction between aromatic carbonyls and alkynes has received increasing attention since 2002 [29,30]. This transformation has been shown to be promoted by Lewis acids, copper complexes [31] and various gold species, including $\mathrm{Au}(\mathrm{I}) \mathrm{X}, \mathrm{Au}(\mathrm{III}) \mathrm{X}_{3},[32-34]$ and $\mathrm{Au}$ nanoparticles dispersed on different supports. For Au(III) catalysts, the reaction has been proposed to proceed via the formation of no less than four organogold intermediates and/or complexes (Figure 1).

Further, it has been shown computationally by Straub that $\mathrm{Au}(\mathrm{I})$ and $\mathrm{Au}(\mathrm{III})$ can perform both this and related catalytic cycles with similar energy profiles [35]. This blurs the distinction of the two pathways and raises the possibility that the actual active species in these transformations could be either species, providing that the possibility exists for the starting Au complex to be oxidized or reduced under a specific set of reaction conditions. Given the complexity of this process, we thought that benzannulation would be an ideal transformation to investigate the use of gold films for MACOS.

\section{Results and Discussion}

Our investigation started with an assessment of different types of metal films for their utility in benzannulation. The morpho$\operatorname{logy}$ of $\mathrm{Cu}, \mathrm{Pd}, \mathrm{Ag}$, and $\mathrm{Au}$ films can be compared in the scanning electron microscopy (SEM) images in Figure 2. The films are generally prepared in a reducing environment (see Experimental), thus they are expected to be largely $M(0)$, which has been confirmed by energy-dispersive X-ray (EDX) analysis of the films (e.g., see panel $f$ in Figure 2).

However, film preparation was not conducted under a strictly inert environment, thus oxygen and/or water in the air could play a role in the film's composition leading to the formation metal oxides, for example, on the surface. Palladium films had the greatest porosity (panel b) while silver films (panel c) were the most dense and uniform. Gold films showed poor adhesion to the glass and poor performance when subjected to the rigors of MACOS. However, these properties were dramatically improved when the same gold film was laid down on a transparently-thin silver layer that coated the capillary wall. With these metal-film-coated capillaries in hand, benzannulation was investigated using the substrates shown in Table 1.

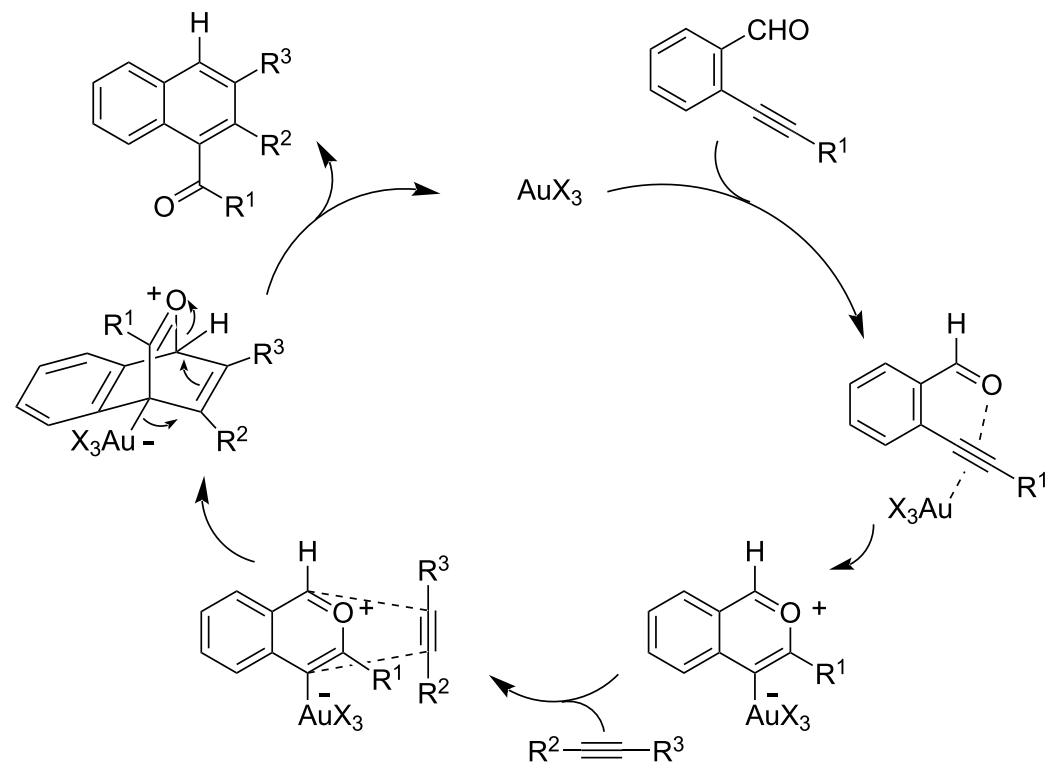

Figure 1: Mechanism of $\mathrm{Au}(\mathrm{III})$-catalyzed benzannulation between aromatic carbonyls and alkynes. 


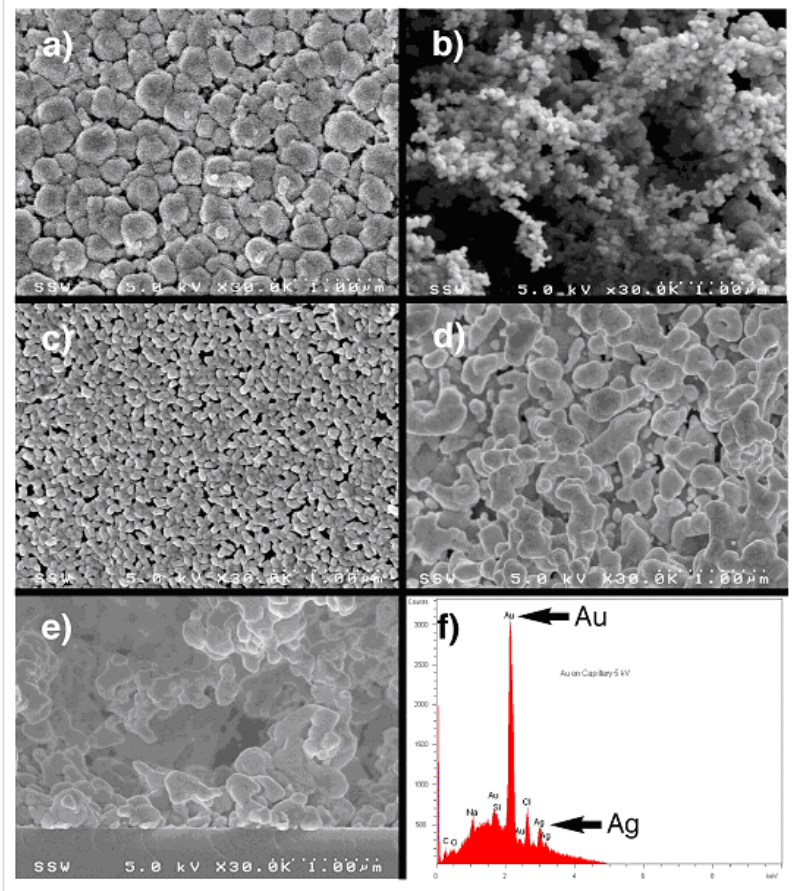

Figure 2: X-ray analysis of the metal films used in this benzannulation study. Panels a-e are scanning-electron micrographs (SEM) of all films taken at 30,000 × magnification: a) $\mathrm{Cu}$, b) Pd, c) $\mathrm{Ag}$, d) $\mathrm{Au}$ layered on a base film of $\mathrm{Ag}$. Panel e shows the side view of the $\mathrm{Au}$ film attached to the glass capillary wall (bottom of image), between which is sandwiched a barely-visible thin Ag coating. Panel $f$ is the energy-dispersive X-ray (EDX) spectrum of the Au film from panel d; note the small level of $\mathrm{Ag}$ that is present that helps to anchor the Au to the surface of the glass.
This reaction is reported most widely using homogeneous and heterogeneous gold catalysts, and indeed we found that a pure $\mathrm{Au}$ film provided good conversion for a short period (Table 1, entry 4), although the film had a short lifespan. Films of palladium (entry 2) and silver (entry 3 ) showed no conversion of starting materials at all. Surprisingly, copper, which is reported to be a suitable catalyst for benzannulation, could not be optimized beyond the formation of only trace amounts of product (entry 1). We experimented with the use of bimetallic films and found that optimal film performance was achieved by laying down a porous gold film on top of a thin silver mirror. When run at a high temperature $\left(240{ }^{\circ} \mathrm{C}\right.$, entry 5$)$, as read by the IR sensor in the Biotage Initiator microwave, excellent conversion was achieved that diminished as the temperature was reduced (e.g., $190^{\circ} \mathrm{C}$, entry 6). It is noteworthy that under batch conditions, these reactions are reported to require up to $6 \mathrm{~h}$ to obtain similar conversion levels [7] to those obtained in less than $60 \mathrm{~s}$ using MACOS, which is the residence time of any reactant plug in the flow reactor.

To probe any special effect brought about by the microwave in this transformation, the identical transformation in entry 6 was performed using an oil bath to achieve the same temperature (i.e., $190{ }^{\circ} \mathrm{C}$, entry 7) and the conversion was dramatically reduced from 68 to 14 percent. It is possible that superior microwave conversion is the result of localized 'hot spots' in the film that are potentially well above the bulk temperature recorded by the IR sensor when microwave irradiation is used.

Table 1: Optimization Studies for Benzannulation Reaction using MACOS.<smiles>O=Cc1ccccc1C#C[PH2+]</smiles>

$1 \mathrm{a}$ (1.0 equiv) Entry metal film in a $1700 \mu \mathrm{m}$ capillary, $\mathrm{Ph}$ 1,2-dichlorobenzene, $\mathrm{FR}=25 \mu \mathrm{L} / \mathrm{min}$,<smiles>C1#CCCC#C1</smiles>
$2 \mathrm{a}$ (3.0 equiv)<smiles>O=C(c1ccccc1)c1c(-c2ccccc2)ccc2ccccc12</smiles>

3a<smiles>O=C(c1ccccc1)c1cc(-c2ccccc2)cc2ccccc12</smiles>

$4 a$ see below for complet
reaction conditions

Heat Source Temp. $\left({ }^{\circ} \mathrm{C}\right)$
Percent Conversion ${ }^{\mathrm{a}}$
Percent Yield ${ }^{b}$

$3 a: 4 a$

\begin{tabular}{|c|c|c|c|c|c|c|}
\hline 1 & $\mathrm{Cu}$ & microwave & 240 & 5 & 4 & ND \\
\hline 2 & $\mathrm{Pd}$ & microwave & 240 & 0 & 0 & - \\
\hline 3 & $\mathrm{Ag}$ & microwave & 240 & 0 & 0 & - \\
\hline 4 & $\mathrm{Au}$ on $\mathrm{Au}$ & microwave & 220 & 75 & ND & \\
\hline 5 & $\mathrm{Au}$ on $\mathrm{Ag}$ & microwave & 240 & 90 & 78 & $3: 1$ \\
\hline 6 & $\mathrm{Au}$ on $\mathrm{Ag}$ & microwave & 190 & 68 & ND & ND \\
\hline 7 & $\mathrm{Au}$ on $\mathrm{Ag}$ & oil bathc & 190 & 14 & ND & ND \\
\hline
\end{tabular}

apercent conversion was determined by ${ }^{1} \mathrm{H}$ NMR spectroscopy by comparing the ratio of product peaks (3 and/or 4$)$ to the starting aldehyde (1) from

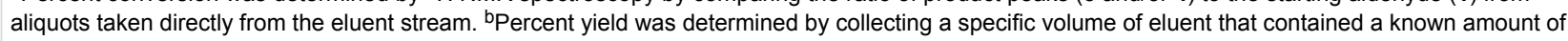
starting materials, and purifying the material by silica gel flash chromatography. ${ }^{C}$ The metal-film-coated capillary was left in the bath for 20 min to ensure that the film was at temperature prior to flowing the reaction mixture through it. 
It has been proposed that steps or angles in the surface of the metal film can serve as an antenna resulting in higher levels of microwave absorption in those areas causing higher than normal temperatures. In an oil bath (or oven), only the bulk temperature of the external heating source can be achieved in the film. If this is the case, and localized areas of potentially extreme temperature are required for optimal reaction performance, this would be preferable to heating the entire film to these higher temperatures, which would lead to faster film and product decomposition.

With optimized conditions in hand, we set out to examine the substrate scope of this reaction using capillaries lined with the gold-on-silver films (Table 2).

Table 2: Benzannulation reactions with Au on Ag-coated capillaries using MACOS.<smiles>[R]C#Cc1[X]cccc1C=O</smiles>

1

(1.0 equiv)

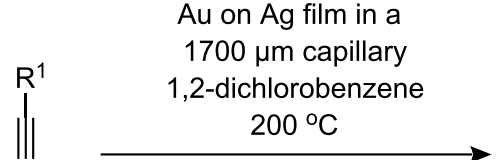

$\mathrm{FR}=25 \mu \mathrm{L} / \mathrm{min}$

75 psi backpressure

Entry R-

2

(3.0 equiv)<smiles>[R]C(=O)c1c([R])ccc2ccc[X]c12</smiles>

3<smiles>[R]C(=O)c1cc([R])cc2ccccc12</smiles>

4

$\begin{array}{llllll}\text { Entry } & \mathrm{R}- & \mathrm{R}^{1}- & \begin{array}{c}\text { Percent } \\ \text { Conversion }\end{array} & \text { Percent Yield } & \text { 3:4 }\end{array}$

a<smiles>Cc1ccccc1</smiles>

$-\mathrm{CH}-$

$-\mathrm{CH}$

$-\mathrm{CH}-$

c<smiles>Cc1ccccc1</smiles>

d<smiles>Cc1ccsc1</smiles>

$-\mathrm{CH}-$

e<smiles>Cc1ccsc1</smiles>

f<smiles>Cc1ccccc1</smiles>

g<smiles>Cc1ccccc1</smiles>

h<smiles>Cc1ccccc1</smiles>

i<smiles>Cc1ccccc1</smiles>

j<smiles>Cc1ccccc1</smiles>

$-\mathrm{N}-$

$-\mathrm{N}-$

$-\mathrm{N}-$

$-\mathrm{N}-$

$-\mathrm{N}-$<smiles>Cc1ccccc1</smiles>

90

78

$75: 25$

$\left(\mathrm{CH}_{3}\right)_{3} \mathrm{Si}-$

75

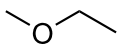

62<smiles>Cc1ccccc1</smiles>

76

62

3 only<smiles>Cc1cccc(C(=O)O)c1</smiles>

72

60

4 only<smiles>Cc1ccccc1</smiles><smiles>Cc1cccc(F)c1</smiles>

68

54

4 only

$\left(\mathrm{CH}_{3}\right)_{3} \mathrm{Si}-$

65

58

4 only<smiles>Cc1ccc(Br)cc1</smiles>

65

52

4 only

$\mathrm{iPr}_{2} \mathrm{NOC}$

50

40

4 only

apercent conversion was determined by ${ }^{1} \mathrm{H}$ NMR spectroscopy by comparing the ratio of product peaks ( 3 and/or 4 ) to the starting aldehyde (1) from aliquots taken directly from the eluent stream. ${ }^{b}$ Percent yield was determined by collecting a specific volume of eluent that contains a known amount of starting materials, and purifying the material by silica gel flash chromatography. 
The reaction was applicable to the hydrocarbon starting materials tried (e.g., entries a, b, c) and was also useful for the preparation of heterocycle-containing molecules such as pyridines and thiophenes (e.g., entries $\mathbf{e}-\mathbf{j}$ ). A survey of different functional groups revealed a broad tolerance including silyl groups (entries $\mathbf{b}$ and $\mathbf{h}$ ), halides (entries $\mathbf{g}$ and $\mathbf{i}$ ), ethers, (entry $\mathbf{c}$ ), amides (entry $\mathbf{j}$ ), and even free carboxylic acids (entry e). In all cases where reactions did not fully complete, benzaldehyde (1) accounted for the mass balance; crude ${ }^{1} \mathrm{H}$ NMR spectra were very clean showing only residual $\mathbf{1}$, product and trace by products. In most cases, the reactions displayed a high level of regioselectivity.

All of the above runs were conducted on approximately $700 \mu \mathrm{L}$ of an infusing starting material solution (35 min per run), which, after purification, generated $\sim 70-80 \mathrm{mg}$ of final product. Such quantities are ample for evaluation in biological screens. However, larger quantities of a compound can be required, so using the substrates in Table 2, entry a, a larger-scale benzannulation was performed. To improve efficiency and to reduce solvent consumption (and hence waste production) the concentration of both starting materials was tripled. After running the reactor for $90 \mathrm{~min}$, three quarters of a gram of product (3a and 4a, 3:1) were collected. Under these conditions the concentration of alkyne 2a was $4.5 \mathrm{M}$, demonstrating that MACOS can easily handle concentrations that are far above the typical levels $(0.1-0.5 \mathrm{M})$ commonly used in conventionally-heated batch reactors.

The lifetime and durability of the film under the optimized reaction conditions was examined. The transformation in Table 2, entry a was followed over the course of $2 \mathrm{~h}$; reaction performance is optimal at the beginning and slowly, but steadily erodes. Visibly, the film darkens over time, which we attribute to small amounts of starting materials and/or products that char over time on the surface of the hot film; this may lead to the blockage of reaction sites. Additionally, the thin-walled capillary glass softened and in some cases failed after $90 \mathrm{~min}$ of exposure to the hot film. While bulk manufacturing of very large quantities is not yet attainable with the current reactor design, the device is very suitable for preparing library collections of 50-750 $\mathrm{mg}$ of product for evaluation in medicinal chemistry or materials science applications.

\section{Conclusion}

Glass capillaries internally-lined with thin-metal films of gold, copper, silver, and gold-on-silver were prepared and evaluated for their catalytic activity in the microwave-assisted, continuous flow benzannulation of aryl, alkyl and silylalkynes with alkynylbenzaldehydes. Only the gold-on-silver films possessed both the high level of catalytic activity and suitable physical robustness to prepare quantities of product suitable, for example, for biological or material science evaluation purposes (up to $\sim 700 \mathrm{mg}$ ). The reaction showed wide functional group tolerance and good to excellent regioselectivity in the cycloaddition. We are now evaluating new materials to replace the glass tube with the plan of making the process more sustainable.

\section{Experimental}

\section{Microwave irradiation experiments}

All MACOS experiments were performed in $1700 \mu \mathrm{m}$ (ID) borosilicate capillaries, using a single mode Biotage Smith Creator Synthesizer, operating at a frequency of $2.45 \mathrm{GHz}$ with irradiation power from 0 to $300 \mathrm{~W}$. The capillary was fed reactants from Hamilton gastight syringes attached to a Harvard 22 syringe pump pre-set to the desired flow rate. The system was connected to a sealed collection vial, where a pressurized air line (75 psi) was attached to create backpressure. The temperatures reported were measured off the surface of the capillaries by the IR sensor built into the microwave chamber. All reagents and solvents were purchased from commercial sources and used without additional purification. Column chromatography purifications were carried out using the flash technique on silica gel 60 (200-400 mesh). ${ }^{1} \mathrm{H}$ NMR spectroscopy was run using a Bruker Advance $400 \mathrm{MHz}$ instrument and all spectra were calibrated to the signal from the residual proton of the deuterated chloroform solvent ( $7.26 \mathrm{ppm}) ;{ }^{13} \mathrm{C}$ NMR spectra were calibrated to the middle carbon signal of the triplet for deuterated chloroform (77.00 ppm).

\section{General procedure for the benzannulation reactions by MACOS}

A stock solution containing the acetylenic aldehyde $(0.5 \mathrm{mmol}$, 1.0 equiv.) and alkyne ( $1.5 \mathrm{mmol}, 3.0$ equiv) in $0.7-0.8 \mathrm{~mL} 1,2-$ dichloro benzene (total mixture volume is $1.0 \mathrm{~mL}$ ) was prepared and loaded into a Hamilton gastight syringe. The tubing was primed with 1,2-dichloro benzene and the syringe was connected to the reactor system with the aid of Microtight fittings after which it was placed in a Harvard 22 syringe pump that was set to deliver $20 \mu \mathrm{L} / \mathrm{min}$. The single mode microwave was programmed to heat constantly; the power level was controled manually so as to keep the temperature constant at the specified levels. The effluent from the reactor was fed into a sealed vial and analyzed directly by ${ }^{1} \mathrm{H}$ NMR spectroscopy immediately after the reaction. Typically, $0.7-0.8 \mathrm{~mL}$ of the crude reaction mixture was collected and the product was purified by silica gel column chromatography. 


\section{General procedure for creating the gold-on-} silver film coating inside of 1700 micron (ID)

\section{capillaries}

Tollens' reagent $(0.5 \mathrm{~mL})$ was mixed with $0.5 \mathrm{~mL}$ of a $5 \%$ D-glucose solution into a $2 \mathrm{~mL}$ vial. The $1700 \mu \mathrm{m}$ capillaries (ID) were filled with this mixture, capped at both ends and left to develop at rt. After the Ag coating was fully developed (15 $\mathrm{min})$, the capillaries were rinsed with acetone and placed inside a muffle furnace for calcination at $500{ }^{\circ} \mathrm{C}(3 \times 1 \mathrm{~min})$.

The gold-coating solution was prepared by mixing a $0.4 \mathrm{mmol} /$ $\mathrm{mL}$ aqueous solution of $\mathrm{AuCl}_{3}(0.5 \mathrm{~mL})$ with a $2 \%$ aqueous solution of sodium citrate $(0.5 \mathrm{~mL})$. The Ag-lined capillaries were filled with the mixture, capped at both ends, and left to develop at $\mathrm{rt}$ for an additional $30 \mathrm{~min}$. After emptying the capillaries and rinsing them with acetone, they were calcinated at $500^{\circ} \mathrm{C}(3 \times 1 \mathrm{~min})$ before use in MACOS.

Tollen's reagent was prepared as follows: $2.0 \mathrm{~mL}$ of $4 \mathrm{M} \mathrm{NaOH}$ was added drop-wise to $20 \mathrm{~mL}$ of a $3 \% \mathrm{AgNO}_{3}$ solution, forming a gray precipitate that was titrated with a $4 \mathrm{M}$ solution of $\mathrm{NH}_{4} \mathrm{OH}$ until the solution became clear.

\section{General procedure for synthesis of benzalde-} hydes [36]<smiles>[R]C#C[O]</smiles>

(1.0 equiv) (1.6 equiv)
$\mathrm{Pd}\left(\mathrm{PPh}_{3}\right)_{4}(0.0375 \mathrm{mmol})$, Cul $(0.075 \mathrm{mmol})$,

\section{$\mathrm{Et}_{3} \mathrm{~N}(1.5 \mathrm{mmol})$,} THF, $70^{\circ} \mathrm{C}$<smiles>[R]C#Cc1[Y]([X])cccc1C=O</smiles>

A $10 \mathrm{~mL}$ round-bottom flask was charged with $\mathrm{Pd}\left(\mathrm{PPh}_{3}\right)_{4}$ (0.0375 mmol), CuI (0.075 mmol), and purged with argon. To it were added consecutively: THF $(6 \mathrm{~mL}), \mathrm{Et}_{3} \mathrm{~N}(1.5 \mathrm{mmol})$, the aryl bromide $(0.75 \mathrm{mmol})$, and the alkyne $(0.9 \mathrm{mmol})$. The solution was then heated to $70{ }^{\circ} \mathrm{C}$ and stirred for $6-13 \mathrm{~h}$ (until the reaction was judged complete by tlc analysis). At the end of the reaction, the mixture was diluted with $\mathrm{H}_{2} \mathrm{O}(10 \mathrm{~mL})$ and extracted with ethyl acetate $(3 \times)$. The combined organic layers were dried over anhydrous $\mathrm{Na}_{2} \mathrm{SO}_{4}$, concentrated, the residue dry loaded onto silica gel and purified by column chromatography.

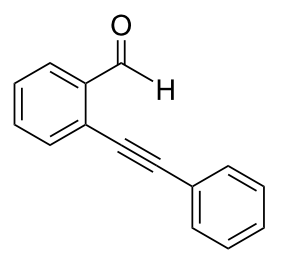

2-(2-Phenylethynyl)benzaldehyde (1a). Following the general procedure for the synthesis of benzaldehydes, column chromatography ( $10 \%$ diethyl ether in pentane) provided $141 \mathrm{mg}$ of product as a pale-brown oil (91\%, yield). ${ }^{1} \mathrm{H}$ NMR $(300 \mathrm{MHz}$, $\left.\mathrm{CDCl}_{3}\right): \delta 10.67(\mathrm{~s}, 1 \mathrm{H}), 7.96(\mathrm{~d}, J=7.8 \mathrm{~Hz}, 1 \mathrm{H}), 7.63(\mathrm{t}, J=$ $4.5 \mathrm{~Hz}, 1 \mathrm{H}), 7.57(\mathrm{~m}, 3 \mathrm{H}), 7.44(\mathrm{t}, J=7.2 \mathrm{~Hz}, 1 \mathrm{H}), 7.41-7.37$ $(\mathrm{m}, 3 \mathrm{H}) .{ }^{13} \mathrm{C} \mathrm{NMR}\left(75 \mathrm{MHz}, \mathrm{CDCl}_{3}\right): \delta 191.6,135.8,133.8$, 133.2, 131.7, 129.1, 128.6, 128.5, 127.3, 126.9, 122.4, 96.4, 85.0. Spectra matched that found in the literature [37].<smiles>O=Cc1ccccc1C#Cc1ccsc1</smiles>

2-[2-(Thiophen-3-yl)ethynyl]benzaldehyde (1d). Following the general procedure for the synthesis of benzaldehydes, column chromatography ( $10 \%$ diethyl ether in pentane) provided $142 \mathrm{mg}$ of the product as a pale-yellow oil $(89 \%$, yield). ${ }^{1} \mathrm{H}$ NMR $\left(300 \mathrm{MHz}, \mathrm{CDCl}_{3}\right): \delta 10.63(\mathrm{~s}, 1 \mathrm{H}), 7.95(\mathrm{~d}, J$ $=8.1 \mathrm{~Hz}, 1 \mathrm{H}), 7.66-7.51(\mathrm{~m}, 3 \mathrm{H}), 7.43(\mathrm{t}, J=7.8 \mathrm{~Hz}, 1 \mathrm{H}), 7.34$ $(\mathrm{dd}, J=5.1,3.0 \mathrm{~Hz}, 1 \mathrm{H}), 7.23(\mathrm{dd}, J=5.1,1.2 \mathrm{~Hz}, 1 \mathrm{H}) .{ }^{13} \mathrm{C}$ NMR $\left(75 \mathrm{MHz}, \mathrm{CDCl}_{3}\right): \delta 191.7,135.8,133.8,133.1,129.7$ (two carbons overlap), 128.5, 127.3, 126.9, 125.8, 121.4, 91.5, 84.6. HRMS Calcd. for $\mathrm{C}_{13} \mathrm{H}_{8} \mathrm{OS}$ : 212.0296; found: 212.0302: Anal. Calcd. for $\mathrm{C}_{13} \mathrm{H}_{8} \mathrm{OS}$ : C, 73.56; H, 3.80; found C, 73.82; $\mathrm{H}, 3.57$.<smiles>O=Cc1cccnc1C#Cc1ccccc1</smiles>

2-(2-Phenylethynyl)nicotinaldehyde (1f). Following the general procedure for the synthesis of benzaldehydes, column chromatography (30\% diethyl ether in pentane) provided 145 mg of product as a dark-yellow solid (93\%, yield). $\mathrm{Mp}=91-92$ ${ }^{\circ} \mathrm{C} .{ }^{1} \mathrm{H}$ NMR (400 MHz, $\left.\mathrm{CDCl}_{3}\right): \delta 10.70(\mathrm{~s}, 1 \mathrm{H}), 8.85$ (d, $J=$ $3.6 \mathrm{~Hz}, 1 \mathrm{H}), 8.24(\mathrm{~d}, J=7.6 \mathrm{~Hz}, 1 \mathrm{H}), 7.67(\mathrm{~d}, J=6.8 \mathrm{~Hz}, 2 \mathrm{H})$, 7.55-7.30 (m, 4H). ${ }^{13} \mathrm{C}$ NMR (100 MHz, $\left.\mathrm{CDCl}_{3}\right): \delta 190.8$, 154.5, 146.1, 134.9, 132.2, 131.8, 129.9, 128.6, 123.2, 121.2, 96.1, 84.6. HRMS Calcd. for $\mathrm{C}_{14} \mathrm{H}_{9} \mathrm{NO}$ 207.0684; found 207.0685. Anal. Calcd. for $\mathrm{C}_{14} \mathrm{H}_{9} \mathrm{NO}: \mathrm{C}, 81.14 ; \mathrm{H}, 4.38$; found $\mathrm{C}, 81.43 ; \mathrm{H}, 4.60$. Spectra matched that found in the literature [38]. 
<smiles>C#Cc1cccc(C(=O)N(C(C)C)C(C)C)c1</smiles>

3-Ethynyl- $\boldsymbol{N}, \boldsymbol{N}$-diisopropylbenzamide (2j). A $25 \mathrm{~mL}$ roundbottom flask was purged with argon, cooled to $0{ }^{\circ} \mathrm{C}$, and $2.4 \mathrm{~mL}$ of dry THF and $157 \mu \mathrm{L}(1.8 \mathrm{mmol})$ of oxalyl chloride were added. After 20 min., a cooled $\left(0{ }^{\circ} \mathrm{C}\right)$ solution of 3-ethynylbenzoic acid $(1.71 \mathrm{mmol}, 250 \mathrm{mg})$ in $6 \mathrm{~mL}$ of dry THF was added over $10 \mathrm{~min}$. When the addition of acid was complete, 3 drops of DMF were added to the mixture and bubbling was observed. After stirring for $30 \mathrm{~min}$. at $0{ }^{\circ} \mathrm{C}$, the solution was stirred an additional $30 \mathrm{~min}$. at $\mathrm{rt}$, and then cooled back to $0{ }^{\circ} \mathrm{C}$. Into a separate $25 \mathrm{~mL}$ round-bottom flask at $0{ }^{\circ} \mathrm{C}$ were added: $(\mathrm{iPr})_{2} \mathrm{NH}(1.8 \mathrm{mmol}, 260 \mu \mathrm{L}), \mathrm{Et}_{3} \mathrm{~N}(1.8 \mathrm{mmol}, 250 \mu \mathrm{L})$, and 2 $\mathrm{mL}$ of dry THF. The contents of the original flask were then added to this flask where upon fuming was observed and a yellow precipitate began to form. The reaction was warmed to $\mathrm{rt}$, stirred for $16 \mathrm{~h}$, and quenched by the addition of $10 \mathrm{~mL}$ of water. After stirring for $10 \mathrm{~min}$., the contents were then transferred to a separatory funnel and ethyl acetate was added. The separated organic layer was washed with sat $\mathrm{NaHCO}_{3}$ and the aqueous layer was back-extracted twice with ethyl acetate. The combined organic layers were washed with brine, dried over anhydrous $\mathrm{Na}_{2} \mathrm{SO}_{4}$, and filtered. Following solvent removal in vacuo, the yellow solid residue was dry-loaded onto silica gel and purified by column chromatography using a gradient elution (5\% ethyl acetate in pentane to $15 \%$ ethyl acetate in pentane, $\left.\mathrm{R}_{\mathrm{f}}=0.5\right)$ to give $390 \mathrm{mg}$ product as a white solid $(99 \%$ yield). $\mathrm{Mp}=107-108{ }^{\circ} \mathrm{C} .{ }^{1} \mathrm{H}$ NMR $\left(400 \mathrm{MHz}, \mathrm{CDCl}_{3}\right): \delta 7.49$ (d, $J=7.6 \mathrm{~Hz}, 1 \mathrm{H}), 7.43(\mathrm{~s}, 1 \mathrm{H}), 7.36(\mathrm{t}, J=8.4 \mathrm{~Hz}, 1 \mathrm{H}), 7.28$ $(\mathrm{d}, J=8.4 \mathrm{~Hz}, 1 \mathrm{H}), 7.32(\mathrm{~d}, 2 \mathrm{H}), 3,09(\mathrm{~s}, 1 \mathrm{H}), 1.33(\mathrm{~d}, 12 \mathrm{H})$ ${ }^{13} \mathrm{C}$ NMR $\left(150 \mathrm{MHz}, \mathrm{CDCl}_{3}, 10{ }^{\circ} \mathrm{C}\right): \delta 169.8,139.0,132.2$, 129.1, 128.6, 125.9, 122.4, 82.9, 77.9, 51.0, 45.9, 20.7, 20.6 HRMS Calcd. for $\mathrm{C}_{15} \mathrm{H}_{19} \mathrm{NO}$ : 229.1467; found: 229.1466 . Anal. Calcd. for $\mathrm{C}_{15} \mathrm{H}_{19} \mathrm{NO}$ : C, 78.56; H, 8.35; found C, 78.61; $\mathrm{H}, 8.71$.

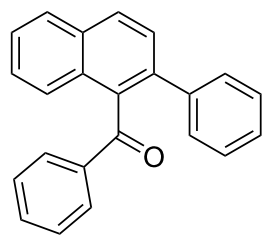

Phenyl-(2-phenylnaphthalen-1-yl)-methanone (3a). Following the general MACOS benzannulation protocol, 2-(2phenylethynyl)-benzaldehyde (1a) and phenylacetylene were reacted and $700 \mu \mathrm{L}$ of the crude reaction mixture were collected. Purification by flash chromatography (15\% ethyl acetate in hexane) afforded $62 \mathrm{mg}$ of $\mathbf{3 a}$ and $20 \mathrm{mg}$ of $\mathbf{4 a}$ as yellow oils $(78 \%$ combined yield, minor isomer reported below). ${ }^{1} \mathrm{H}$ NMR (400 MHz, $\left.\mathrm{CDCl}_{3}\right): \delta 8.2(\mathrm{~d}, J=8.2 \mathrm{~Hz}, 1 \mathrm{H})$, $7.95(\mathrm{~d}, J=8.3 \mathrm{~Hz}, 1 \mathrm{H}), 7.78(\mathrm{~d}, J=8.1 \mathrm{~Hz}, 1 \mathrm{H}), 7.65(\mathrm{~m}, 2 \mathrm{H})$, $7.58(\mathrm{~d}, J=8.3 \mathrm{~Hz}, 1 \mathrm{H}), 7.35-7.52(\mathrm{~m}, 5 \mathrm{H}), 7.15-7.30(\mathrm{~m}, 5 \mathrm{H})$. ${ }^{13} \mathrm{C}$ NMR $\left(100 \mathrm{MHz}, \mathrm{CDCl}_{3}\right): \delta 199.8,140.4,137.9,137.6$, $137.2,133.4,132.5,130.5,129.5,129.4,129.3,128.3,128.1$, $128.0,127.6,127.2,127.0,126.4,125.5$. Spectra matched that found in the literature [39].<smiles>O=C(c1ccccc1)c1cc(-c2ccccc2)cc2ccccc12</smiles>

Phenyl-(3-phenylnaphthalen-1-yl)-methanone (4a). ${ }^{1} \mathrm{H}$ NMR $\left(400 \mathrm{MHz}, \mathrm{CDCl}_{3}\right) \delta 8.15(\mathrm{~d}, J=1.1 \mathrm{~Hz}, 1 \mathrm{H}), 7.98(\mathrm{~d}, J=8.2$ $\mathrm{Hz}, 1 \mathrm{H}), 7.90(\mathrm{~d}, J=8.0 \mathrm{~Hz}, 1 \mathrm{H}), 7.80(\mathrm{~d}, J=8.0 \mathrm{~Hz}, 2 \mathrm{H})$, $7.72(\mathrm{~d}, J=1.1 \mathrm{~Hz}, 1 \mathrm{H}), 7.58(\mathrm{~d}, J=8.0 \mathrm{~Hz}, 2 \mathrm{H}), 7.50(\mathrm{tt}, J=$ 7.4, 1.0 Hz, 1H), 7.37-7.47 (m, 6H), $7.30(\mathrm{tt}, J=7.4,1.0 \mathrm{~Hz}$, 1H). ${ }^{13} \mathrm{C} \mathrm{NMR}\left(100 \mathrm{MHz}, \mathrm{CDCl}_{3}\right): \delta 197.7,139.9,138.2$, $137.2,137.0,134.2,133.4,130.5,130.1,129.0,128.8,128.6$, $128.3,127.8,127.2,127.0,126.9,126.7,125.7$. Spectra matched that found in the literature [40].<smiles>C[Si](C)(C)c1cc(C(=O)c2ccccc2)c2ccccc2c1</smiles>

Phenyl-(3-trimethylsilanyl-naphthalen-1-yl)-methanone (4b). Following the general MACOS benzannulation protocol, 2-(2-phenylethynyl)-benzaldehyde (1a) and TMS-acetylene were reacted and $740 \mu \mathrm{L}$ of the crude reaction mixture were collected. Purification by flash chromatography (15\% ethyl acetate in hexane) afforded $68.9 \mathrm{mg}$ of $\mathbf{4 b}$ as a white solid (62\% yield). $\mathrm{Mp}=86-87^{\circ} \mathrm{C}$ (lit. [34]: $88^{\circ} \mathrm{C}$ ). ${ }^{1} \mathrm{H}$ NMR (400 MHz, $\left.\mathrm{CDCl}_{3}\right): \delta 8.17(\mathrm{~d}, J=1.1 \mathrm{~Hz}, 1 \mathrm{H}), 8.05(\mathrm{~d}, J=8.2 \mathrm{~Hz}, 1 \mathrm{H})$, 7.85-7.95 (m, 3H), 7.68 (d, $J=1.1 \mathrm{~Hz}, 1 \mathrm{H}), 7.45-7.60$ (m, 5H), $0.35(\mathrm{~s}, 9 \mathrm{H}) .{ }^{13} \mathrm{C} \mathrm{NMR}\left(100 \mathrm{MHz}, \mathrm{CDCl}_{3}\right): \delta 198.5,138.3$, $136.8,136.5,135.5,133.3,133.0,131.6,131.1,130.5,128.5$, $128.3,127.4,126.4,125.6,-1.20$. Spectra matched that found in the literature [34]. 
<smiles>COCc1ccc2ccccc2c1C(=O)c1ccccc1</smiles>

[2-(Methoxymethyl)naphthalen-1-yl]-phenylmethanone (3c). Following the general MACOS benzannulation protocol, 2-(2phenylethynyl)-benzaldehyde (1a) and methyl propargyl ether were reacted and $815 \mu \mathrm{L}$ of the crude reaction mixture were collected. Purification by flash chromatography (15\% ethyl acetate in pentane) afforded $58.0 \mathrm{mg}$ of $\mathbf{3 c}$ and $\mathbf{4 c}$ isomers as colourless oils (52\% combined yield, 58:42, respectively).

(3c) ${ }^{1} \mathrm{H}$ NMR $\left(400 \mathrm{MHz}, \mathrm{CDCl}_{3}\right): \delta 7.98(\mathrm{~d}, J=8.1 \mathrm{~Hz}, 1 \mathrm{H})$, $7.92(\mathrm{~d}, J=8.1 \mathrm{~Hz}, 1 \mathrm{H}), 7.84(\mathrm{~d}, J=8.1 \mathrm{~Hz}, 2 \mathrm{H}), 7.53-7.66(\mathrm{~m}$, $3 \mathrm{H}), 7.37-7.52(\mathrm{~m}, 4 \mathrm{H}), 4.50(\mathrm{~s}, 2 \mathrm{H}), 3.23(\mathrm{~s}, 3 \mathrm{H}) .{ }^{13} \mathrm{C} \mathrm{NMR}$ $\left(100 \mathrm{MHz}, \mathrm{CDCl}_{3}\right): \delta 199.2,137.8,135.7,133.7,133.3,132.8$, 130.4, 129.6, 129.4, 128.7, 128.2, 126.8, 126.2, 125.5, 125.4, 72.1, 58.3. Anal. Calcd. for $\mathrm{C}_{19} \mathrm{H}_{16} \mathrm{O}_{2}$ : C, 82.58; H, 5.84; found, $\mathrm{C}, 82.34, \mathrm{H}$, 5.60. HRMS calcd. for $\mathrm{C}_{19} \mathrm{H}_{16} \mathrm{O}_{2}$ : 276.1150 ; found 276.1154 .<smiles>COCc1cc(C(=O)c2ccccc2)c2ccccc2c1</smiles>

[3-(Methoxymethyl)naphthalen-1-yl]-phenylmethanone (4c). ${ }^{1} \mathrm{H}$ NMR $\left(400 \mathrm{MHz}, \mathrm{CDCl}_{3}\right): \delta 8.06(\mathrm{~d}, J=8.1 \mathrm{~Hz}, 1 \mathrm{H}), 7.98(\mathrm{~d}$, $J=1.1 \mathrm{~Hz}, 1 \mathrm{H}), 7.93(\mathrm{~d}, J=8.1 \mathrm{~Hz}, 1 \mathrm{H}), 7.89(\mathrm{~d}, J=8.1 \mathrm{~Hz}$, $2 \mathrm{H}), 7.10(\mathrm{t}, J=7.1 \mathrm{~Hz}, 1 \mathrm{H}), 7.58(\mathrm{~d}, J=1.1 \mathrm{~Hz}, 1 \mathrm{H})$, $7.45-7.56(\mathrm{~m}, 4 \mathrm{H}), 4.66(\mathrm{~s}, 2 \mathrm{H}), 3.46(\mathrm{~s}, 3 \mathrm{H}) .{ }^{13} \mathrm{C}$ NMR $(100$ $\left.\mathrm{MHz}, \mathrm{CDCl}_{3}\right): \delta 197.9,138.2,136.7,134.4,133.7,133.3$, 130.5, 130.4, 129.4, 128.5, 128.3, 127.3, 127.1, 126.7, 125.6, 74.2, 58.3. Anal. Calcd. for $\mathrm{C}_{19} \mathrm{H}_{16} \mathrm{O}_{2}$ : C, 82.58; $\mathrm{H}, 5.84$; found $\mathrm{C}, 82.39 ; \mathrm{H}, 5.62$. HRMS calcd. for $\mathrm{C}_{19} \mathrm{H}_{16} \mathrm{O}_{2}$ : 276.1150; found 276.1153 .

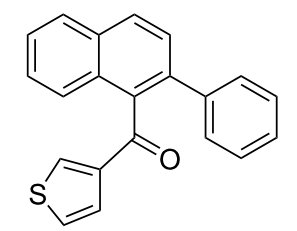

[2-(Phenyl)naphthalen-1-yl](thiophen-3-yl)-methanone (3d). Following the general MACOS benzannulation protocol, 2-(2- (thiophen-3-yl)-ethynyl)-benzaldehyde (1d) and phenylacetylene were reacted and $650 \mu \mathrm{L}$ of the crude reaction mixture were collected. Purification by flash chromatography ( $15 \%$ ethyl acetate in hexane) afforded $63.7 \mathrm{mg}$ of $\mathbf{3 d}$ as a paleyellow oil (62\% yield). ${ }^{1} \mathrm{H}$ NMR (400 $\left.\mathrm{MHz}, \mathrm{CDCl}_{3}\right)$ : $\delta 8.04(\mathrm{~d}$, $J=8.1 \mathrm{~Hz}, 1 \mathrm{H}), 7.96(\mathrm{~d}, J=8.1 \mathrm{~Hz}, 1 \mathrm{H}), 7.84(\mathrm{~d}, J=8.1 \mathrm{~Hz}$, $1 \mathrm{H}), 7.61(\mathrm{~d}, J=8.1 \mathrm{~Hz}, 1 \mathrm{H}), 7.48-7.58(\mathrm{~m}, 3 \mathrm{H}), 7.38-7.47(\mathrm{~m}$, $3 \mathrm{H}), 7.21-7.34(\mathrm{~m}, 3 \mathrm{H}), 7.12-7.15(\mathrm{~m}, 1 \mathrm{H}) .{ }^{13} \mathrm{C}$ NMR $(100$ $\left.\mathrm{MHz}, \mathrm{CDCl}_{3}\right): \delta 198.6,143.5,140.3,137.1,136.4,135.3$, 132.4, 130.4, 129.6, 129.4, 128.3, 128.1, 127.6, 127.5, 127.3, 127.2, 126.4, 126.2, 125.5. Anal. Calcd. for $\mathrm{C}_{21} \mathrm{H}_{14} \mathrm{OS}$ : C, 80.22; H, 4.49; found C, 79.79; H, 4.13. HRMS calcd. for $\mathrm{C}_{21} \mathrm{H}_{14} \mathrm{OS}$ : 314.0765 ; found 314.0759 .<smiles>O=C(O)c1cccc(-c2cc(C(=O)c3ccsc3)c3ccccc3c2)c1</smiles>

3-[4-(Thiophene-3-carbonyl)naphthalen-2-yl]-benzoic acid (4e). Following the general MACOS benzannulation protocol, 2-(2-(thiophen-3-yl)-ethynyl)-benzaldehyde (1d) and 3-ethynylbenzoic acid were reacted and $700 \mu \mathrm{L}$ of the crude reaction mixture were collected. Purification by flash chromatography (10\% methanol in dichloromethane) afforded $75.0 \mathrm{mg}$ of $4 \mathbf{e}$ as a yellow oil (60\% yield). ${ }^{1} \mathrm{H}$ NMR $\left(400 \mathrm{MHz}, \mathrm{CDCl}_{3}\right): \delta 8.17$ (s, $1 \mathrm{H}), 8.10(\mathrm{~d}, J=8.1 \mathrm{~Hz}, 1 \mathrm{H}), 7.93-8.00(\mathrm{~m}, 2 \mathrm{H}), 7.82(\mathrm{~d}, J=$ $8.1 \mathrm{~Hz}, 1 \mathrm{H}), 7.67(\mathrm{~d}, J=8.1 \mathrm{~Hz}, 1 \mathrm{H}), 7.48-7.63(\mathrm{~m}, 4 \mathrm{H})$, 7.33-7.43 (m, 2H), 7.15 (s, 1H). ${ }^{13} \mathrm{C} \mathrm{NMR}\left(150 \mathrm{MHz}, \mathrm{CDCl}_{3}\right)$ : $\delta 192.7,171.3,143.4,140.6,136.7,135.7,135.3,134.6,132.6$, $130.8,130.3,129.7,129.4,129.1,128.4,128.1,127.3,127.2$, 127.0, 126.6, 126.4, 125.5. HRMS calcd. for $\mathrm{C}_{22} \mathrm{H}_{14} \mathrm{O}_{3} \mathrm{~S}$ : 358.0664 ; found 358.0666 .

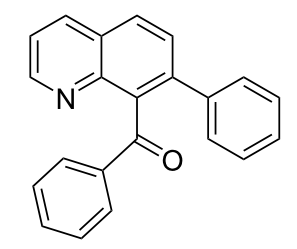

Phenyl-(7-phenylquinolin-8-yl)-methanone (3f). Following the general MACOS benzannulation protocol, 2-(2phenylethynyl)-nicotinaldehyde (1f) and phenyl acetylene were reacted and $780 \mu \mathrm{L}$ of the crude reaction mixture were collected. Purification by flash chromatography $(20 \%$ ethyl acetate in pentane) afforded $77.8 \mathrm{mg}$ of $\mathbf{3 f}$ and $\mathbf{4 f}$ isomers as pale-yellow oils $\left(64 \%\right.$ combined yield). (3f) ${ }^{1} \mathrm{H}$ NMR (400 
$\left.\mathrm{MHz}, \mathrm{CDCl}_{3}\right): \delta 8.88(\mathrm{dd}, J=4.1,1.5 \mathrm{~Hz}, 1 \mathrm{H}), 8.25(\mathrm{~d}, J=8.1$ $\mathrm{Hz}, 1 \mathrm{H}), 8.01(\mathrm{~d}, J=8.1 \mathrm{~Hz}, 1 \mathrm{H}), 7.66-7.73(\mathrm{~m}, 3 \mathrm{H}), 7.40-7.47$ (m, 4H), 7.20-7.33 (m, 5H). ${ }^{13} \mathrm{C} \mathrm{NMR}\left(100 \mathrm{MHz}, \mathrm{CDCl}_{3}\right): \delta$ 198.8, 151.1, 146.6, 140.5, 139.3, 137.9, 137.4, 135.7, 133.0, 129.6, 129.3, 128.7, 128.6, 128.3, 128.2, 127.7, 127.0, 121.4. HRMS calcd. for $\mathrm{C}_{22} \mathrm{H}_{15} \mathrm{NO}$ : 309.1154; found 309.1145 .<smiles>O=C(c1ccccc1)c1cc(-c2ccccc2)cc2cccnc12</smiles>

Phenyl-(6-phenylquinolin-8-yl)-methanone (4f). ${ }^{1} \mathrm{H}$ NMR $\left(400 \mathrm{MHz}, \mathrm{CDCl}_{3}\right): \delta 8.86(\mathrm{dd}, J=4.1,1.5 \mathrm{~Hz}, 1 \mathrm{H}), 8.29$ (dd, $J$ $=8.1,1.5 \mathrm{~Hz}, 1 \mathrm{H}), 8.16(\mathrm{~d}, J=2.0 \mathrm{~Hz}, 1 \mathrm{H}), 8.03(\mathrm{~d}, J=2.0 \mathrm{~Hz}$, $1 \mathrm{H}), 7.92(\mathrm{dd}, J=8.1,1.5 \mathrm{~Hz}, 2 \mathrm{H}), 7.75(\mathrm{dd}, J=8.1,1.5 \mathrm{~Hz}$, 2H), $7.59(\mathrm{t}, J=7.1 \mathrm{~Hz}, 1 \mathrm{H}), 7.49-7.56(\mathrm{~m}, 2 \mathrm{H}), 7.40-7.49(\mathrm{~m}$, $4 \mathrm{H}) .{ }^{13} \mathrm{C} \mathrm{NMR}\left(100 \mathrm{MHz}, \mathrm{CDCl}_{3}\right): \delta 197.7,150.8,145.6$, $139.8,139.5,138.7,137.7,136.2,133.3,130.3,129.1,128.5$, 128.3, 128.1, 127.9, 127.5, 127.1, 122.0. Anal. Calcd. for $\mathrm{C}_{22} \mathrm{H}_{15} \mathrm{NO}$ : C, 85.40; N, 4.53; H, 4.89; found C, 84.98; N, 4.32; $\mathrm{H}, 4.62$. HRMS calcd. for $\mathrm{C}_{22} \mathrm{H}_{15} \mathrm{NO}$ : 309.1154; found 309.1143 .

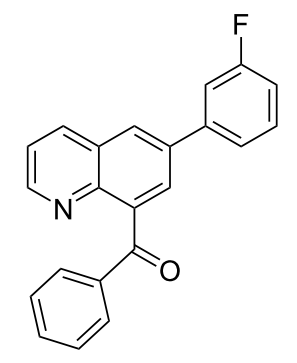

[6-(3-Fluorophenyl)quinolin-8-yl](phenyl)methanone (4g). Following the general MACOS benzannulation protocol, 2-(2phenylethynyl)-nicotinaldehyde (1f) and 1-ethynyl-3-fluorobenzene were reacted and $750 \mu \mathrm{L}$ of the crude reaction mixture were collected. Purification by flash chromatography $(25 \%$ ethyl acetate in pentane) afforded $63.8 \mathrm{mg}$ of $\mathbf{4} \mathbf{g}$ as a colourless oil (54\% yield). ${ }^{1} \mathrm{H}$ NMR (400 MHz, $\mathrm{CDCl}_{3}$ ): $\delta 8.87$ (dd, $J=$ $4.0,1.5 \mathrm{~Hz}, 1 \mathrm{H}), 8.29$ (dd, $J=8.1,1.5 \mathrm{~Hz}, 1 \mathrm{H}), 8.15$ (d, $J=2.0$ $\mathrm{Hz}, 1 \mathrm{H}), 7.99(\mathrm{~d}, J=2.0 \mathrm{~Hz}, 1 \mathrm{H}), 7.90(\mathrm{dd}, J=8.1,1.5 \mathrm{~Hz}$, 2H), 7.60 (t, $J=7.1 \mathrm{~Hz}, 1 \mathrm{H}), 7.40-7.56(\mathrm{~m}, 6 \mathrm{H}), 7.10-7.17$ (m, 1H). ${ }^{13} \mathrm{C} \mathrm{NMR}\left(100 \mathrm{MHz}, \mathrm{CDCl}_{3}\right): \delta 197.6,163.3\left({ }^{1} \mathrm{~J}^{13} \mathrm{C}-{ }^{19} \mathrm{~F}=\right.$ $245.0 \mathrm{~Hz}), 151.1,145.7,141.8,141.7,140.1,137.6$, 137.5, $136.2,133.4,130.6\left({ }^{3} J^{13} \mathrm{C}-{ }^{19} \mathrm{~F}=8.5 \mathrm{~Hz}\right), 130.2,128.4,127.5$, $127.3,123.1,122.1,114.9\left({ }^{2} J^{13} \mathrm{C}-{ }^{19} \mathrm{~F}=22.0 \mathrm{~Hz}\right), 114.4\left({ }^{2} \mathrm{~J}^{13} \mathrm{C}-\right.$ ${ }^{19} \mathrm{~F}=23.0 \mathrm{~Hz}$ ). Anal. Calcd. for $\mathrm{C}_{22} \mathrm{H}_{14} \mathrm{FNO}$ : C, 80.72; N,
4.28; H, 4.31; found C, 80.77; N, 4.56; H, 4.09. HRMS calcd. for $\mathrm{C}_{22} \mathrm{H}_{14} \mathrm{FNO}$ : 327.1059; found 327.1046.<smiles>C[Si](C)(C)c1cc(C(=O)c2ccccc2)c2ncccc2c1</smiles>

Phenyl-[6-(trimethylsilyl)quinolin-8-yl]methanone (4h). Following the general MACOS benzannulation protocol, 2-(2phenylethynyl)-nicotinaldehyde (1f) and TMS acetylene were reacted and $800 \mu \mathrm{L}$ of the crude reaction mixture were collected. Purification by flash chromatography $(20 \%$ ethyl acetate in pentane) afforded $70.0 \mathrm{mg}$ of $\mathbf{4 h}$ as a pale-brown oil (58\% yield). ${ }^{1} \mathrm{H}$ NMR (400 MHz, $\mathrm{CDCl}_{3}$ ): $\delta 8.82$ (dd, $J=4.1$, $1.5 \mathrm{~Hz}, 1 \mathrm{H}), 8.21(\mathrm{dd}, J=8.1,1.5 \mathrm{~Hz}, 1 \mathrm{H}), 8.11(\mathrm{~d}, J=1.6 \mathrm{~Hz}$, $1 \mathrm{H}), 7.84-7.87(\mathrm{~m}, 3 \mathrm{H}), 7.55(\mathrm{t}, J=7.6 \mathrm{~Hz}, 1 \mathrm{H}), 7.38-7.44(\mathrm{~m}$, $3 \mathrm{H}), 0.38(\mathrm{~s}, 9 \mathrm{H}) .{ }^{13} \mathrm{C} \mathrm{NMR}\left(100 \mathrm{MHz}, \mathrm{CDCl}_{3}\right): \delta 198.5$, 151.0, 146.4, 138.9, 138.3, 137.9, 136.0, 135.5, 133.2, 132.1, $130.2,128.3,127.5,121.7,0.87$. Anal. Calcd. for $\mathrm{C}_{19} \mathrm{H}_{19} \mathrm{NOSi}$ : C, 74.71; N, 4.59; H, 6.27; found C, 74.93; N, 4.62; H, 6.07. HRMS calcd. for $\mathrm{C}_{19} \mathrm{H}_{19} \mathrm{NOSi}$ : 305.1236; found 305.1232.<smiles>O=C(c1ccccc1)c1cc(-c2ccc(Br)cc2)cc2cccnc12</smiles>

[6-(4-Bromophenyl)quinolin-8-yl]-phenylmethanone (4i). Following the general MACOS benzannulation protocol, 2-(2phenylethynyl)-nicotinaldehyde (1f) and 1-bromo-4-ethynylbenzene were reacted and $700 \mu \mathrm{L}$ of the crude reaction mixture were collected. Purification by flash chromatography $(20 \%$ ethyl acetate in pentane) afforded $70.0 \mathrm{mg}$ of $\mathbf{4 i}$ as a colourless oil (52\% yield). ${ }^{1} \mathrm{H}$ NMR (400 MHz, $\mathrm{CD}_{2} \mathrm{Cl}_{2}$ ): $\delta 8.83$ (dd, $J=$ $4.1,1.5 \mathrm{~Hz}, 1 \mathrm{H}), 8.35$ (dd, $J=8.1,1.5 \mathrm{~Hz}, 1 \mathrm{H}), 8.21$ (d, $J=2.0$ $\mathrm{Hz}, 1 \mathrm{H}), 8.00(\mathrm{~d}, J=2.0 \mathrm{~Hz}, 1 \mathrm{H}), 7.85$ (dd, $J=8.1,1.5 \mathrm{~Hz}$, 2H), 7.60-7.76 (m, 4H), 7.44-7.56 (m, 3H), 7.34 (q, $J=9.0 \mathrm{~Hz}$, 1H). ${ }^{13} \mathrm{C}$ NMR $\left(150 \mathrm{MHz}, \mathrm{CD}_{2} \mathrm{Cl}_{2}\right): \delta 197.3,150.7,145.4$, $140.0,138.5,137.8,137.5,136.2,133.2,132.1,129.8,128.9$, $128.4,128.3,127.2,126.9,122.3,122.1$. HRMS calcd. for $\mathrm{C}_{22} \mathrm{H}_{14} \mathrm{BrNO}[\mathrm{M}+\mathrm{H}]^{+}$: 388.0337 ; found 388.0337 . 
<smiles>CC(C)N(C(=O)c1cccc(-c2cc(C(=O)c3ccccc3)c3ncccc3c2)c1)C(C)C</smiles>

3-(8-benzoylquinolin-6-yl)- $N, N$-diisopropylbenzamide (4j) Following the general MACOS benzannulation protocol, 2-(2phenylethynyl)-nicotinaldehyde (1f) and 3-ethynyl-N,N-diisopropylbenzamide were reacted and $840 \mu \mathrm{L}$ of the crude reaction mixture were collected. Purification by flash chromatography (30\% ethyl acetate in pentane) afforded $72.0 \mathrm{mg}$ of $\mathbf{4} \mathbf{j}$ as a colourless oil (40\% yield). ${ }^{1} \mathrm{H}$ NMR $\left(600 \mathrm{MHz}, \mathrm{CD}_{2} \mathrm{Cl}_{2}\right): \delta$ $8.81(\mathrm{dd}, J=3.8,1.6 \mathrm{~Hz}, 1 \mathrm{H}), 8.35(\mathrm{dd}, J=8.1,1.6 \mathrm{~Hz}, 1 \mathrm{H})$, $8.25(\mathrm{~d}, J=2.1 \mathrm{~Hz}, 1 \mathrm{H}), 8.03(\mathrm{~d}, J=2.1 \mathrm{~Hz}, 1 \mathrm{H}), 7.84(\mathrm{dd}, J=$ $8.1,1.6 \mathrm{~Hz}, 2 \mathrm{H}), 7.79(\mathrm{~d}, J=8.1 \mathrm{~Hz}, 1 \mathrm{H}), 7.70(\mathrm{~s}, 1 \mathrm{H}), 7.61(\mathrm{t}$, $J=7.6 \mathrm{~Hz}, 1 \mathrm{H}), 7.56(\mathrm{t}, J=7.6 \mathrm{~Hz}, 1 \mathrm{H}), 7.44-7.52(\mathrm{~m}, 3 \mathrm{H})$, $7.35(\mathrm{~d}, J=8.1 \mathrm{~Hz}, 1 \mathrm{H}), 3.90($ br s, $1 \mathrm{H}), 3.54$ (br s, $1 \mathrm{H}), 1.55$ (s, $6 \mathrm{H}), 1.16(\mathrm{~s}, 6 \mathrm{H}) .{ }^{13} \mathrm{C} \mathrm{NMR}\left(150 \mathrm{MHz}, \mathrm{CD}_{2} \mathrm{Cl}_{2} 10{ }^{\circ} \mathrm{C}\right): \delta$ 197.6, 170.2, 150.7, 145.5, 140.2, 140.0, 139.9, 138.1, 137.8, $136.3,133.3,129.9,129.2,128.5,128.4,127.5,127.4,127.2$, $124.9,124.6,122.2,51.0,45.7,20.4$. HRMS calcd. for $\mathrm{C}_{29} \mathrm{H}_{28} \mathrm{~N}_{2} \mathrm{O}_{2}$ : 436.2151 ; found 436.2147 .

\section{Supporting Information}

Spectra for compounds made in this manuscript are available as supporting information.

\section{Supporting Information File 1}

NMR spectra of compounds $\mathbf{1 d}, \mathbf{2 j}, \mathbf{3 c}, \mathbf{3 d}, \mathbf{3 f}, \mathbf{4 c}$ and $\mathbf{4 e - j}$.

[http://www.beilstein-journals.org/bjoc/content/

supplementary/1860-5397-5-35-S1.pdf]

\section{Acknowledgments}

This work was funded by the Ontario Research and Development Challenge Fund (ORDCF), NSERC (Canada), Dalton Pharma Inc., Bruker Biospin Inc., and York University. The authors are grateful to Biotage Inc. for the donation of a Smith Creator Synthesizer ${ }^{\mathrm{TM}}$ and to Syrris Inc. for the donation of the components of an AFRICA microreactor flow system to develop this new methodology. We acknowledge Ross Davidson at Surface Science Western, University of Western Ontario, London, ON for the SEM and EDX measurements.

\section{References}

1. Tierney, P. J.; Lidstrom, P. Microwave Assisted Organic Synthesis; Blackwell Publishing: Oxford, 2005.

2. Kappe, C. O. Angew. Chem., Int. Ed. 2004, 43, 6250-6284. doi:10.1002/anie.200400655

3. Jähnisch, K.; Hessel, V.; Löwe, H.; Baerns, M. Angew. Chem., Int. Ed. 2004, 43, 406-446. doi:10.1002/anie.200300577

4. Pennemann, H.; Watts, P.; Haswell, S. J.; Hessel, V.; Löwe, H. Org. Process Res. Dev. 2004, 8, 422-439. doi:10.1021/op0341770

5. Bremner, S.; Organ, M. G. J. Comb. Chem. 2007, 9, 14-16. doi:10.1021/cc060130p

6. Comer, E.; Organ, M. G. J. Am. Chem. Soc. 2005, 127, 8160-8167. doi:10.1021/ja0512069

7. Comer, E.; Organ, M. G. Chem.-Eur. J. 2005, 11, 7223-7227. doi:10.1002/chem.200500820

8. Bagley, M. C.; Jenkins, R. L.; Lubinu, M. C.; Mason, C.; Wood, R. J. Org. Chem. 2005, 70, 7003-7006. doi:10.1021/jo0510235

9. Saaby, S.; Baxendale, I. R.; Ley, S. V. Org. Biomol. Chem. 2005, 3, 3365-3368. doi:10.1039/b509540a

10. He, P.; Haswell, S. J.; Fletcher, P. D. I. Appl. Catal., A 2004, 274, 111-114.

11. Cablewski, T.; Faux, A. F.; Strauss, C. R. J. Org. Chem. 1994, 59 , 3408-3412. doi:10.1021/jo00091a033

12. Glasnov, T. N.; Kappe, C. O. Macromol. Rapid Commun. 2007, 28 395-410. doi:10.1002/marc.200600665

13. Glasnov, T. N.; Vugts, D. J.; Koningstein, M. M.; Desai, B.; Fabian, W. M. F.; Orru, R. V. A.; Kappe, C. O. QSAR Comb. Sci. 2006, 25, 509-518. doi:10.1002/qsar.200540210

14. Wilson, N. S.; Sarko, C. R.; Roth, G. Org. Process Res. Dev. 2004, 8, 535-538. doi:10.1021/op034181b

15. Wiles, C.; Watts, P. Eur. J. Org. Chem. 2008, 10, 1655-1671. doi:10.1002/ejoc.200701041

16. Wheeler, R. C.; Benali, O.; Deal, M.; Farrant, E.; MacDonald, S. J. F.; Warrington, B. H. Org. Process Res. Dev. 2007, 11, 704-710. doi:10.1021/op7000707

17. Baxendale, I. R.; Hayward, J. J.; Ley, S. V. Comb. Chem. High Throughput Screening 2007, 10, 802-836. doi:10.2174/138620707783220374

18. Brivio, M.; Verboom, W.; Reinhoudt, D. N. Lab Chip 2006, 6, 329-344. doi:10.1039/b510856j

19. Wild, G. P.; Wiles, C.; Watts, P. Lett. Org. Chem. 2006, 3, 419-425. doi:10.2174/157017806777828475

20. Watts, P.; Haswell, S. J. Drug Discovery Today 2003, 8, 586-593. doi:10.1016/S1359-6446(03)02732-6

21. Jones, R. V.; Csajagi, C.; Szekelyhidi, Z.; Kovacs, I.; Borcsek, B.; Urge, L.; Darvas, F. Chim. Oggi 2008, 26 (3), 10-12.

22. Kikutani, Y.; Kitamori, T. Macromol. Rapid Commun. 2004, 25 , 158-168. doi:10.1002/marc.200300192

23. Stonestreet, P.; Harvey, A. P. Chem. Eng. Res. Des. 2002, 80, 31-44. doi:10.1205/026387602753393204

24. Vasudevan, D.; Basha, C. A. Bull. Electrochem. 2000, 16, 341-344.

25. Shore, G.; Organ, M. G. Chem.-Eur. J. 2008, 14, 9641-9646. doi:10.1002/chem.200801610

26. Shore, G.; Organ, M. G. Chem. Commun. 2008, 838-840. doi:10.1039/b715709f

27. Shore, G.; Morin, S.; Mallik, D.; Organ, M. G. Chem.-Eur. J. 2008, 14, 1351-1356. doi:10.1002/chem.200701588

28. Shore, G.; Morin, S.; Organ, M. G. Angew. Chem., Int. Ed. 2006, 45 2761-2766. doi:10.1002/anie.200503600

29. Hashmi, A. S. K. Gold Bull. 2003, 36, 3-9. 
30. Asao, N. Synlett 2006, 1645-1656. doi:10.1055/s-2006-947331

31. Asao, N.; Nogami, T.; Lee, S.; Yamamoto, Y. J. Am. Chem. Soc. 2003, 125, 10921-10925. doi:10.1021/ja036927r

32. Hashmi, A. S. K.; Frost, T. M.; Bats, J. W. J. Am. Chem. Soc. 2000, 122, 11553-11554. doi:10.1021/ja005570d

33. Hashmi, A. S. K.; Frost, T. M.; Bats, J. W. Org. Lett. 2001, 3, 3769-3771. doi:10.1021/ol016734d

34. Asao, N.; Takahashi, K.; Lee, S.; Kasahara, T.; Yamamoto, Y. J. Am. Chem. Soc. 2002, 124, 12650-12651. doi:10.1021/ja028128z

35. Straub, B. F. Chem. Commun. 2004, 1726-1728. doi:10.1039/b404876h

36. Obika, S.; Kono, H.; Yasui, R.; Yanada, Y.; Takemoto, Y. J. Org. Chem. 2007, 72, 4462-4468. doi:10.1021/jo070615f

37. Dai, G.; Larock, R. C. Org. Lett. 2001, 3, 4035-4038. doi:10.1021/ol0102085

38. Dyker, G.; Stirner, W.; Henkel, G. Eur. J. Org. Chem. 2000, 8, 1433-1441. doi:10.1002/(SICI)1099-0690(200004)2000:8<1433::AID-EJOC1433>3 .0.CO;2-7

39. Barluenga, J.; Vasquez-Villa, H.; Ballesteros, A.; Gonzalez, J. M. Org. Lett. 2003, 5, 4121-4124. doi:10.1021/ol035691t

40. Asao, N.; Aikawa, A.; Yamammoto, Y. J. Am. Chem. Soc. 2004, 126, 7458-7459. doi:10.1021/ja0477367

\section{License and Terms}

This is an Open Access article under the terms of the Creative Commons Attribution License

(http://creativecommons.org/licenses/by/2.0), which permits unrestricted use, distribution, and reproduction in any medium, provided the original work is properly cited.

The license is subject to the Beilstein Journal of Organic Chemistry terms and conditions:

(http://www.beilstein-journals.org/bjoc)

The definitive version of this article is the electronic one which can be found at: $\underline{\text { doi:10.3762/bjoc. } 5.35}$ 